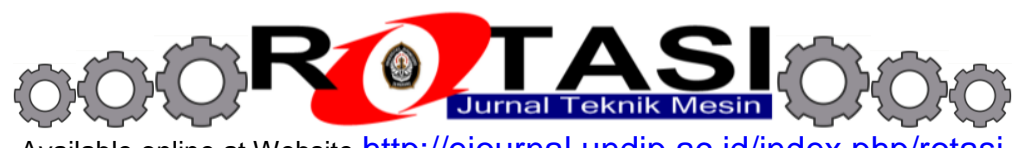

Available online at Website http://ejournal.undip.ac.id/index.php/rotasi

\title{
PERUBAHAN NILAI KEKERASAN DAN KONDUKTIVITAS LISTRIK ALUMINIUM AKIBAT PROSES EQUAL CHANNEL ANGULAR PRESSING (ECAP)
}

\author{
*Rusnaldy, Norman Iskandar, Muhammad Khairul Rais, Wisnu Tri Erlangga \\ Jurusan Teknik Mesin, Fakultas Teknik, Universitas Diponegoro \\ J1. Prof. Soedarto SH, Tembalang, Semarang 50275 Indonesia Telp/Fax: +62 247460059 \\ *E-mail: rusnaldy@undip.ac.id
}

\begin{abstract}
In current study, Equal Channel Angular Pressing (ECAP) process was applied to pure aluminium rod. The effect of the number of passes on hardness and electrical conductivity ECAP samples was investigated. The dimensions of ECAP die for $12 \mathrm{mmm}$ diameter workpieces are designed with intersect angle of $120^{\circ}$. The experiments were carried out by using samples cut from an ingot and a rod and machined to a size of $12 \mathrm{~mm}$ in diameter and $50 \mathrm{~mm}$ in length. The workpiece was pressed into the ECAP die up to 7 passes at room temperature.After deformation, all samples were subjected to a hardness test, an electrical conductivity test and for optical microscope study. The hardness measurement of the ECAP samples suggested that enhanced hardness would be obtained by repeating ECAP process.Increasing the electrical conductivity of the ECAP samples indicatesthat there is no dislocation formation due to increasing plastic deformation in ECAP process.
\end{abstract}

Keywords: ECAP, Aluminium, number of passes, hardness and electrical conductivity

\section{PENDAHULUAN}

Equal channel angular pressing (ECAP) adalah salah satu proses severe plastic deformation (SPD). SPD termasuk dalam proses pembentukan logam (metal forming). Tujuan utama proses SPD adalah untuk menghasilkan komponen yang memiliki kekuatan tinggi dan ringan serta ramah lingkungan [1]. Proses ECAP ini memiliki prospek yang cerah untuk menghasilkan bahan baku pembuatan komponen otomotif sehingga diharapkan dapat menghemat penggunaan bahan bakar.

Dengan proses ini akan dihasilkan produk dengan butir yang sangat halus dan kekuatan yang jauh lebih tinggi. Dengan hasil seperti ini maka produk dari proses ECAP dapat dijadikan sebagai bahan baku untuk komponen yang terbuat dari produk logam, dimana komponen yang dibuat akan menjadi lebih tipis atau kecil ukurannya dengan kekuatan yang sama atau lebih tinggi dibanding dengan produk yang selama ini digunakan. Keuntungan lain dengan menggunakan proses ini adalah prosesnya dapat dilakukan pada temperatur kamar, sehingga tidak memerlukan fasilitas tambahan untuk pemanas, serta tidak memerlukan tambahan energi listrik untuk proses pemanasannya

Mengingat jumlah kendaraan bermotor di Indonesia sebagai alat transportasi dari tahun ke tahun semakin meningkat, maka pengembangan proses ECAP sebagai salah satu proses pembuatan komponen otomotif patut dipertimbangkan. Menurut data dari Biro Pusat Statistik [2], jumlah total kendaraan bermotor pada tahun 2011 adalah 85,60 juta unit yang terdiri dari mobil penumpang (9,55 juta unit), bis (2,25 juta unit), truk (4,96 juta unit) dan sepeda motor $(68,84$ juta unit). Tentu saja dengan jumlah kendaraan bermotor sebesar itu akan membutuhkan jumlah suku cadang atau komponen otomotif yang sangat besar. Sebagian besar komponen kendaran bermotor tersebut masih terbuat dari logam. Dan proses produksi yang banyak digunakan untuk hal tersebut saat ini adalah proses permesinan logam.

Skematik dari proses ECAP dapat dilihat pada Gambar 1. Dari Gambar tersebut dapat dilihat bahwa proses ECAP membutuhkan cetakan dan penekan (plunger) untuk mendorong benda kerja dari satu sisi ke sisi yang lain dengan sudut channel yang dapat divariasikan.

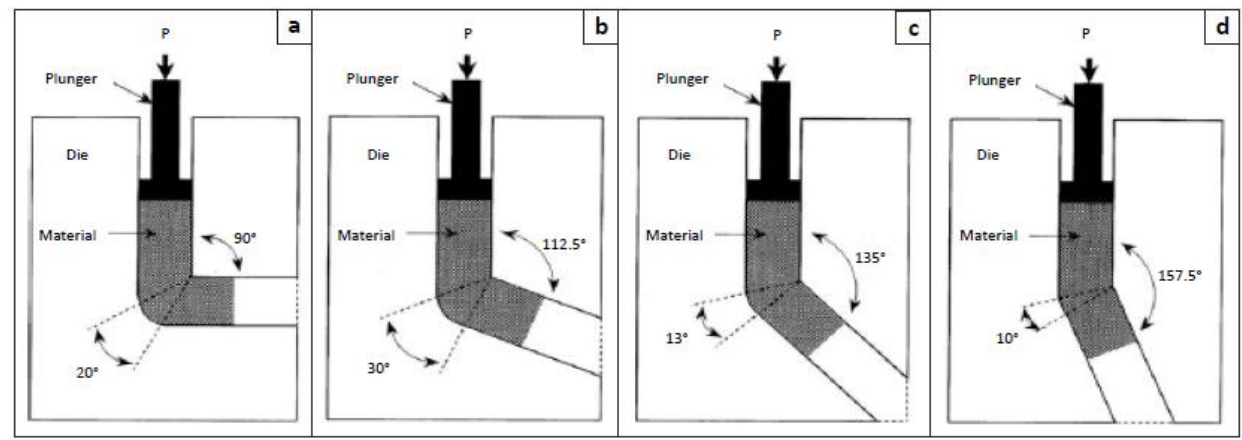

Gambar 1. Ilustrasi dari proses ECAP dengan sudut channel yang berbeda-beda [3] 
Deformasi yang terjadi saat benda kerja didorong diilustrasikan pada Gambar 2. Pada zona yang membentuk sudut dalam cetakan (deformation zone-DZ) terjadi regangan (strain) yang cukup besar yang dialami oleh logam (lihat Gambar 3). Hal ini yang menyebabkan ukuran butir logam menjadi sangat halus (lihat Gambar 4) dan kekuatannya menjadi sangat tinggi (lihat Gambar 5).

Pada studi ini, proses ECAP akan coba diterapkan pada logam aluminium murni. Seberapa besar peningkatan kekerasan dan konduktivitas listrik logam yang dihasilkan setelah mengalami proses ECAP akan dikaji dan dievaluasi. Konduktivitas listrik diukur untuk melihat apakah kenaikan nilai kekerasan logam diiringi dengan meningkatnya kerapatan dislokasi yang umum terjadi pada logam yang mengalami deformasi plastis. Peningkatan kerapatan dislokasi akan terlihat dengan menurunnya konduktivitas listrik.

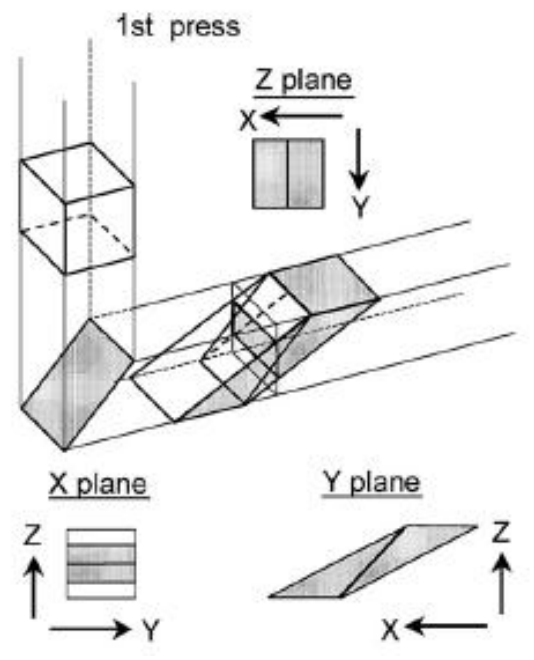

Gambar 2. Deformasi yang terjadi pada benda kerja saat proses ECAP berlangsung [1]

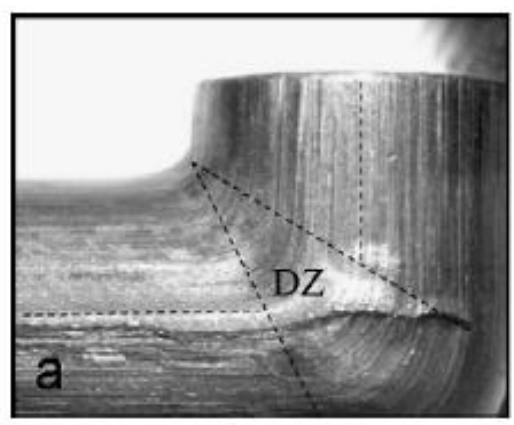

Gambar 3. Deformation Zone [4]
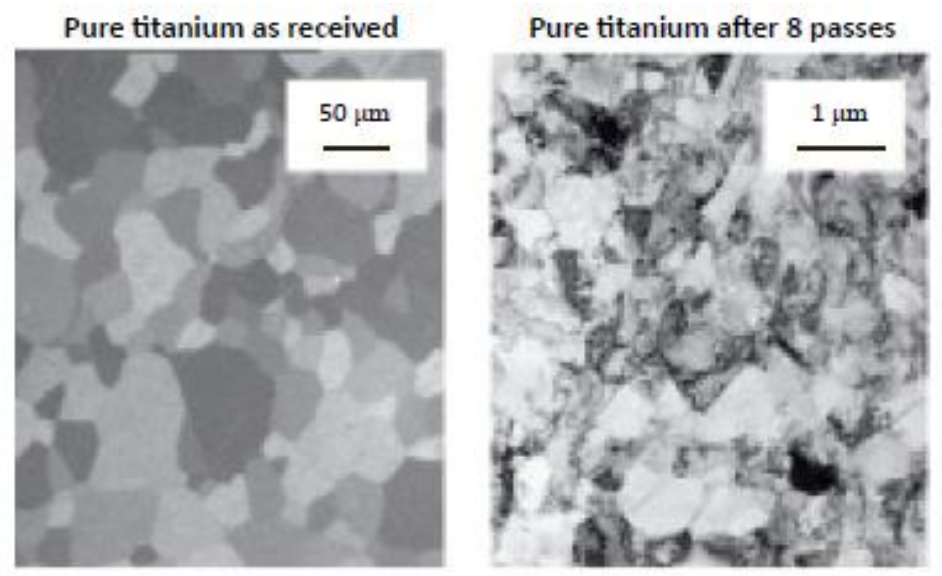

Gambar 4. Contoh ukuran butir sebelum dan setelah mengalami proses ECAP 


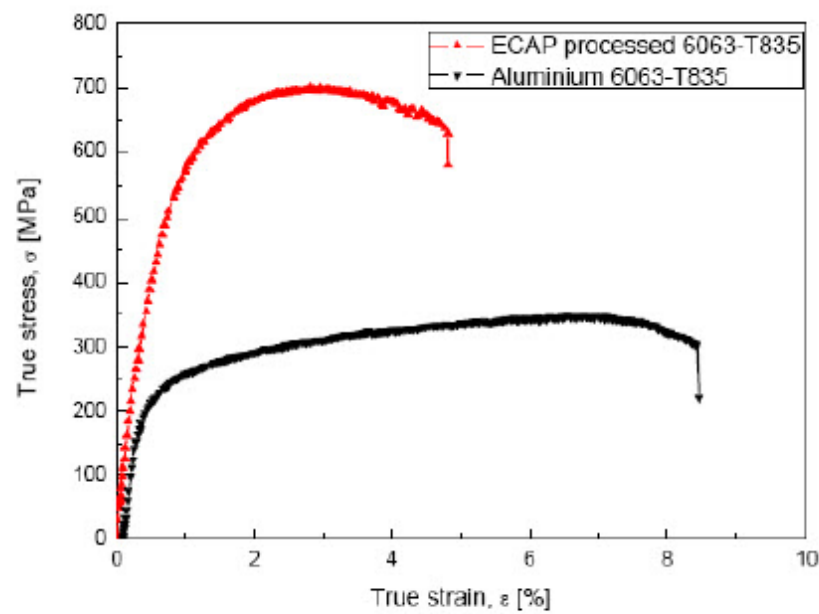

Fig. 2. True stress - true strain diagram for unprocessed and ECAP processed 6063-T835 aluminum alloy

Gambar 5. Contoh perbandingan kekuatan logam dengan menggunakan proses ECAP dan tidak [5].

Keberhasilan studi ini akan dijadikan sebagai landasan untuk mencoba melakukan penelitian dengan logam lain dalam bentuk yang berbeda, seperti memanfaatkan geram hasil proses permesinan dan cake steel (wootz steel). Keberhasilan semua proses ECAP ini akan dilanjutkan dengan membuat komponen otomotif melalui proses permesinan, forging dan ekstrusi.

\section{METODOLOGI}

\section{Material Benda Kerja}

Ada 2 jenis material aluminium yang digunakan pada studi ini, yakni alumunium batangan produk cor (ingot) dan batangan aluminium komersial. Komposisi kimia aluminium komersial dapat dilihat pada tabel 1, sementara sifatsifatnya dapat dilihat pada tabel 2. Dari komposisi kimia dan sifat-sifatnya, batangan aluminium komersial ini termasuk jenis Al 1350. Dimensi benda kerja yang digunakan dalam studi ini memiliki panjang $50 \mathrm{~mm}$ dan diameter $12 \mathrm{~mm}$.

Tabel 1. Komposisi Kimia Batangan Aluminium Komersial

\begin{tabular}{cccccccc}
\hline Unsur & $\mathrm{Al}$ & $\mathrm{Si}$ & $\mathrm{Fe}$ & $\mathrm{Cu}$ & $\mathrm{Mn}$ & $\mathrm{Cr}$ \\
\hline \% Berat & 99,43 & 0,10 & 0,40 & 0,05 & 0,01 & 0,01 \\
\hline
\end{tabular}

Tabel 2. Sifat-sifat Batangan Aluminium Komersial

\begin{tabular}{cccc}
\hline Sifat & Tensile Strength $(\mathrm{MPa})$ & Yield Strength $(\mathrm{MPa})$ & Kond. Listrik $(\% \mathrm{IACS})$ \\
\hline Nilai & 83 & 28 & 61,8 \\
\hline
\end{tabular}

\section{Peralatan Yang Digunakan}

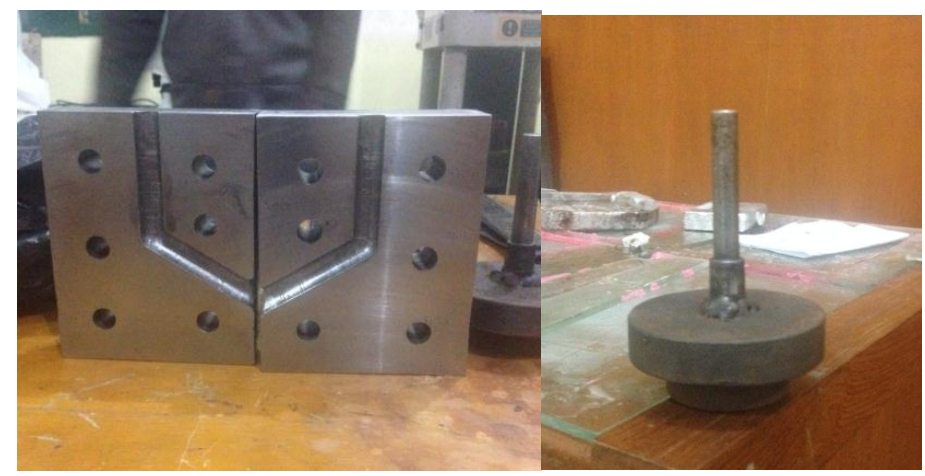

Gambar 6. Cetakan dan penekan yang digunakan pada proses ECAP

Pada studi ini proses ECAP menggunakan cetakan yang terbuat dari tool steel JIS SKD 11, seperti yang terlihat pada Gambar 6. Sudut saluran yang digunakan pada studi ini adalah $120^{\circ}$. Untuk menekan benda kerja digunakan penekan seperti yang terlihat pada Gambar 6. Penekan ini memiliki diameter $12 \mathrm{~mm}$ dan panjang $60 \mathrm{~mm}$. Bentuk dari penekan ini disesuaikan dengan universal testing machine yang digunakan agar pada saat setup alat lebih mudah. 


\section{Proses ECAP}

Cetakan dan jig diletakan pada mesin uji tarik, seperti terlihat pada Gambar 7. Proses ECAP dilakukan dengan cara menekan penekan untuk mendorong aluminium dari saluran atas cetakan hingga keluar pada saluran keluar yang berada disamping cetakan. Proses ini dilakukan secara berulang-ulang untuk memberikan variasi jumlah tekanan yang didapatkan oleh aluminium. Variasi tekanan yang diberikan adalah $0,1,3,5,7$ kali pengulangan.

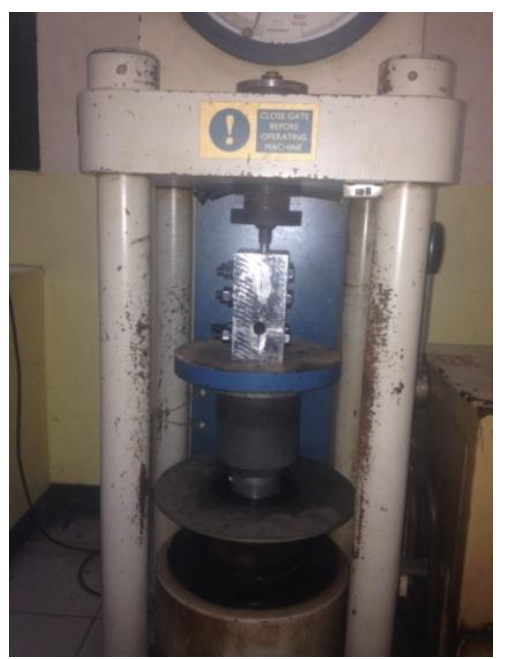

Gambar 7. Setup Pelaksanaan Proses ECAP

\section{Kontrol Kualitas Produk ECAP}

Kualitas hasil proses ECAP ditentukan melalui hal-hal sebagai berikut:

1. Inspeksi visual untuk melihat cacat-cacat yang terjadi pada produk

2. Pengujian kekerasan produk

3. Pengujian konduktivitas listrik

4. Pengamatan struktur mikro

\section{HASIL DAN PEMBAHASAN}

\section{Hasil dan Pembahasan Inspeksi Visual}

Proses ECAP dilakukan pada dua jenis material aluminium yang berbeda, yaitu aluminium cor dan aluminium komersial Al 1350. Hasil proses ECAP dapat dilihat pada Gambar 8 dan 9. Pada Gambar 8 terlihat bahwa permukaan produk hasil proses ECAP dipenuhi oleh retakan di banyak tempat. Hal ini mengindikasikan bahwa banyak terdapat porositas pada benda uji dari aluminium cor. Porositas-porositas tersebut merupakan lokasi awal timbulnya retak pada benda kerja. Sementara pada Gambar 9 hasil yang berbeda diperoleh, dimana permukaan produk hasil ECAP tetap mulus tanpa adanya retakan atay cacat lainnya.

Dari hasil visual inspeksi ini, maka selanjutnya proses ECAP menggunakan materila benda kerja dari aluminium komersial Al 1350.

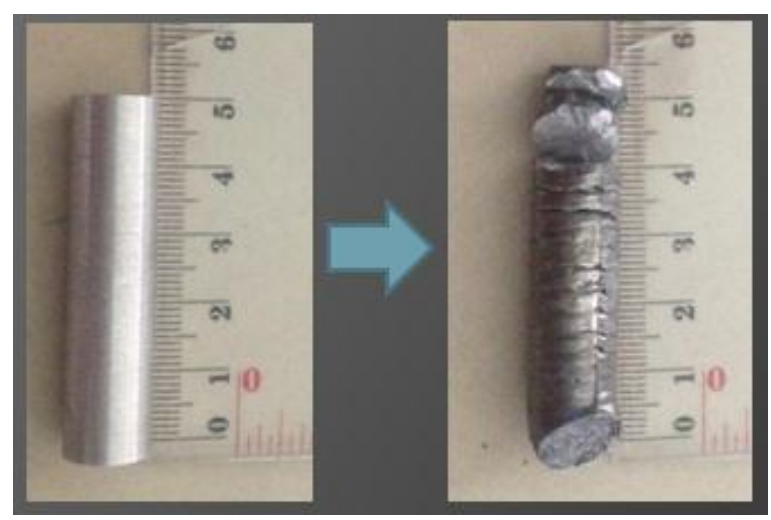

Gambar 8. Hasil Proses ECAP untuk Material Aluminium Cor 


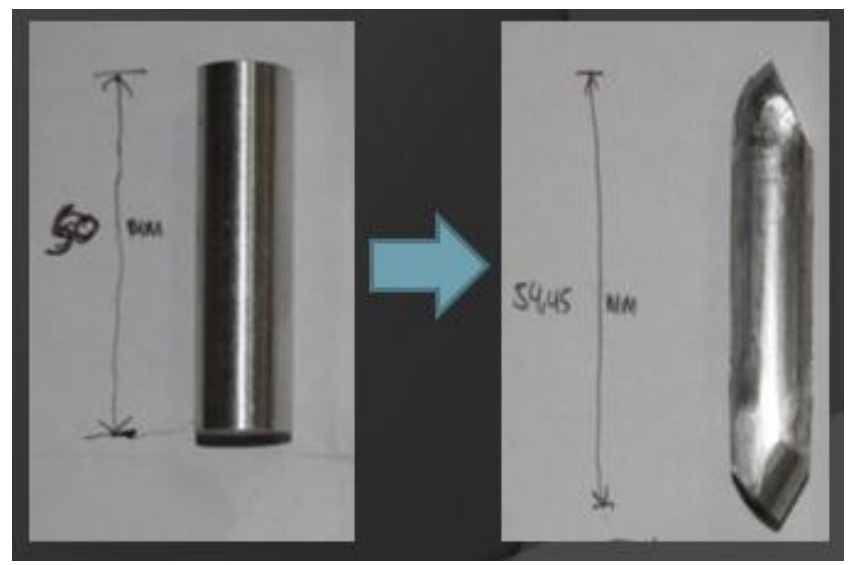

Gambar 9. Hasil Proses ECAP untuk Material Aluminium Al 1350.

\section{Hasil dan Pembahasan Pengujian Kekerasan}

Pengujian kekerasan dilakukan pada bagian selubung silinder produk hasil proses ECAP. Nilai kekerasan yang didapat untuk setiap jumlah langkah proses dapat dilihat pada grafik di Gambar 10. Dari grafik dapat dilihat bahwa nilai kekerasan produk ECAP yang dihasilkan akan meningkat jika jumlah proses ECAP yang dilakukan bertambah banyak. Ada dua kemungkinan yang dapat menyebabkan peningkatan kekerasan yaitu 1) ukuran butir menjadi semakin halus, dan 2) karena adanya efek strain hardening, hal ini terjadi jika jumlah dislokasi yang terjadi pada benda kerja akan semakin banyak. Untuk membuktikan apakah terjadi peningkatan jumlah dislokasi akibat proses ECAP maka perlu dilakukan pengujian konduktivitas listriknya dan untuk membuktikan peningkatan kekerasan terjadi karena berkurangnya ukuran butir maka perlu dilakukan pengamatan struktur mikro.

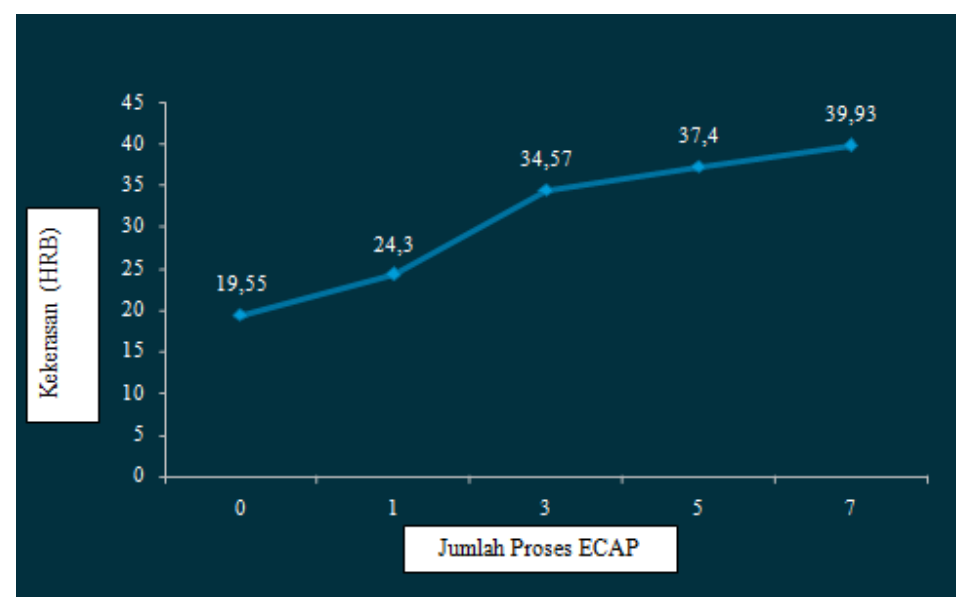

Gambar 10. Pengaruh Jumlah Proses ECAP Terhadap Nilai Kekerasan Produk

\section{Hasil dan Pembahasan Pengujian Konduktivitas Listrik}

Logam dapat menghantarkan listrik karena adanya elektron yang bebas bergerak ketika arus listrik diberikan padanya. Makin bebas dan mudah elektron bergerak akan semakin tinggi nilai konduktivitas listriknya. Sebaliknya jika saat bergerak elektron menemui banyak hambatan maka akan berkurang konduktivitas listriknya. Banyak hal yang dapat menyebabkan elektron mengalami hambatan saat bergerak, salah satunya adalah adanya dislokasi. Semakin banyak kerapatan dislokasi yang menumpuk, terutama pada batas butir, maka akan semakin sulit elektron bergerak, sehingga akan semakin berkurang konduktivitas listriknya.

Untuk melihat apakah peningkatan kekerasan disebabkan karena adanya peningkatan kerapatan dislokasi akibat efek strain hardening, maka dilakukan pengukuran konduktivitas listriknya dan hasilnya dapat dilihat pada Gambar 11. Pada Gambar dapat terlihat bahwa proses ECAP menyebabkan naiknya nilai konduktivitas listrik produk. Hal ini mengindikasikan bahwa proses ECAP tidak menyebabkan peningkatan kerapatan dislokasi pada produk. Sehingga peningkatan kekerasan kemungkinan disebabkan karena meningkatnya kehalusan butir yang dihasilkan sesuai dengan tujuan dari proses ini. 


\section{konduktivitas}

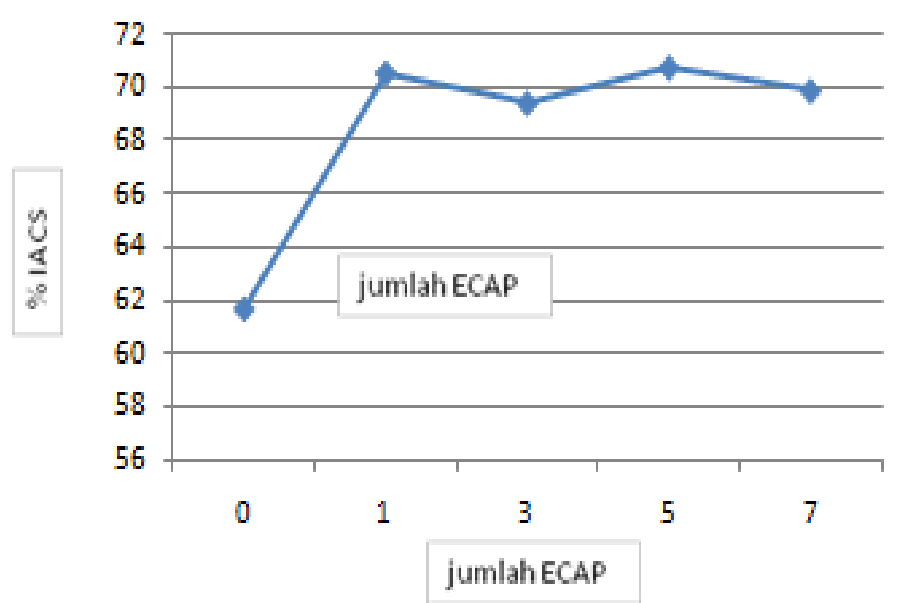

Gambar 11. Pengaruh Jumlah Proses ECAP Terhadap Nilai Konduktivitas Listrik Produk

\section{Hasil dan Pembahasan Pengamatan Struktur Mikro}

Salah satu kendala yang sering ditemui pada pengamatan struktur mikro aluminium seri 1 adalah sukarnya mendapatkan batas butir yang jelas. Pada studi kali ini kendala inipun juga ditemui. Hasil foto struktur mikro dari setiap langkah proses ECAP dapat dilihat pada gambar 12. Dari foto struktur mikro yang diperoleh sulit menarik kesimpulan apakah terjadi peningkatan kehalusan butir atau tidak sehingga diperlukan cara lain untuk mengamatinya seperti dengan menggunakan mikroskop elektron.
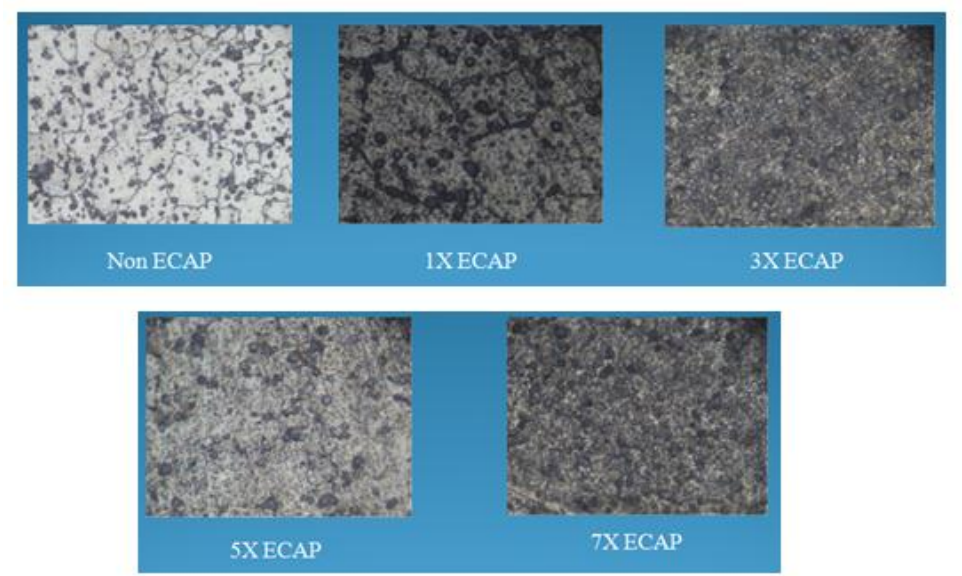

Gambar 12. Pengaruh Jumlah Proses ECAP Terhadap Struktur Mikro (Perbesaran 200x)

\section{KESIMPULAN}

Dari hasil yang diperoleh maka dapat ditarik beberapa kesimpulan sebagai berikut:

1. Proses ECAP dapat dilakukan pada skala laboratorium pada material aluminium. Aluminium cor tidak dapat digunakan sebagai benda kerja karena produk ECAP yang dihasilkan akan mengalami banyak cacat pada permukaan berupa retak.

2. Nilai kekerasan produk ECAP akan meningkat jika jumlah proses ECAP bertambah.

3. Nilai konduktivitas listrik produk ECAP akan menjadi lebih tinggi bila dibanding dengan produk yang tidak mengalami proses ECAP. Hal ini menunjukkan bahwa peningkatan nilai kekerasan produk bukan disebabkan karena adanya efek strain hardening berupa peningkatan kerapatan dislokasi di batas butir.

\section{DAFTAR PUSTAKA}

[1] Azushima, A., Kopp, R., Korhonen, A., Yang, D.Y., Micari, F., Lahoti, G.D., Groche, P., Yanagimoto, J., Tsuji, N., Rosochowski, A., Yangida, A., (2008), Severe plastic deformation (SPD) processes for metals, CIRP Annals Manufacturing Technology 57, pp. 716-735. 
[2] www.bps.go.id, diakses tanggal 12 Juni 2013

[3] Iwahashi, Y., Horita, Z., Nemoto, M., Langdong, T.G., (1998), The process of grain refinement in equal channel angular pressing, Acta Materials A382 (1-2), pp. 30-34.

[4] Han, W.Z., Zhang, Z.F., Wu, S.D., Li, S.X., (2008), Investigation on the geometrical aspect of deformation during equal-channel angular pressing by in-situ physical modeling experiments, Materials Science and Engineering A 476, pp . 224-229.

[5] Cojocaru, V.D., Raducanu, D., Serban, N., Cinca, I., Saban, R., (2010), Mechanical behaviour comparison between unprocessed and ECAP (Equal Channel Angular Pressing) processed 6063-T835 aluminum alloy, U.P.B. Science Bulletin Series B Vol. 72 Issue 3, pp. 193-202. 